\title{
Student's Creative Thinking Ability with The Lesson Study Design in Biology Content
}

\author{
Baiq Fatmwati ${ }^{*}$, Nunung Ariandani1 ${ }^{1}$, Maya Sasmita ${ }^{2}$ \\ ${ }^{1}$ Departement Of Biology Education, Hamzanwadi University, Selong, Indonesia \\ ${ }^{2}$ SDN 4 Rumbuk, Selong, West Nusa Tenggara, Indonesia
}

DOI: $\underline{10.29303 / j p p i p a . v 7 i 2.708}$

\section{Article Info}

Received: March 15 th 2021

Revised: April 18th, 2021

Accepted: April 23 $3^{\text {th }}, 2021$

\begin{abstract}
Some strategies were conducted by educators to create a conducive classroom atmosphere, and create collaborative learning so that students are accustomed to expressing their ideas, and opinions in learning, one of which is by implementing lesson study patterns for learning community. The research focus was to find out students' creative thinking skills in biological materials by using lesson study for learning community learning patterns. The respondents of the study were Grade X IPA students at SMA Negeri 1 Masbagik numbering 33 students. Data collection used a description test of biodiversity. The results of the description test were analyzed using the Scale Range Formula, the description test given referred to indicators of creative thinking ability i.e. fluency, flexibility, and originality and each answer was given a score of 3,2 and 1 . The results of the data analysis were that learning with lesson study patterns for learning community, students were able to produce creative ideas with a moderate category that is above $50 \%$, while for the low and high categories the gain was below $50 \%$ in creative thinking indicators namely fluency, flexibility, and originality. To get used to students getting used to creative thinking, it took exercises in the creative thinking process either in the form of essay questions, or tasks that are implemented during the learning process.
\end{abstract}

Keywords: creative thinking; design learning; lesson stud; biology content.

Citation: Fatmawati, B., Ariandani, N., \& Sasmita, M. (2021). Student's Creative Thinking Ability with The Lesson Study Design in Biology Content. Jurnal Penelitian Pendidikan IPA, 7(2), $287-292$. doi:https://doi.org/10.29303/jppipa.v7i2.708

\section{Introduction}

One of the objectives of the implementation of the 2013 curriculum is to prepare Indonesian people to have life skills such as being productive, creative, and innovative citizens in the face of world civilization. In addition, the demands of technological development also require students to be more creative and innovative, as stated by Kaçan \& Sahin (2018) that with the development of technology and the current trend of globalization, people are required to be more productive and innovative in all life lines. Therefore, the school as a formal institution in charge of helping to prepare reliable human resources must be able to provide a variety of life skills in the learning process. Daud et, al (2012); Diki (2013) also said that educational institutions as a place to learn have an important role in improving quality, skills development, and fostering the creativity of students.

Having creative thinking skills is very important, but in reality, the creative thinking skills of students in Indonesia are still lacking (Husna \& Kurniasih, 2019). Similarly, Chan \&Yuen (2014) stated that developing students' creativity is important, but does not yet have 
a pedagogical strategy to implement it. Because teachers are faced with a pedagogical dilemma to integrate creativity in their application in the classroom (Conradty, 2020). This is because the learning strategy in the classroom is less interesting, Sandika \& Fitrihidajati (2018) stated that students' creative thinking skills and scientific attitudes are still low because the learning methods applied are less effective so that it affects students' motivation and learning achievements. Saptenno et. al (2019) has also made observations after one of the high schools in Ambon that the learning model applied by teachers in learning has not met the demands of the 2013 curriculum which causes students' creative thinking skills to be bad.

As explained that creative thinking is a mental activity, Aguilar \& Turmo (2019) explains a series of mental activities in thinking can be done collaboratively such as brainstorming in discussions that can foster creative thinking. To avoid the dominance of one student at the time of brainstorming in the classroom, innovative techniques are required by the teacher. Observations from Wahdah et. al (2018) shows that the class is dominated by only a few students, therefore learning strategies are needed that can help students be more active in learning and every student has the opportunity to convey ideas freely.

One form of skill that can be implemented by the teachers through learning was creative thinking skills. Creative thinking is a process of thinking or mental activity to provide new solutions to a problem, look at various possible solutions to a problem, find alternatives, come up and come up with new ideas. Csikzentmihalyi (1996) suggested that research on creativity needs to be done to support biology learning in order to improve learning outcomes and prepare for future student careers.

Creative thinking needs to be applied in the learning process because in the future it is useful to face the big challenges in the 21st century, especially now it has entered the era of industrial revolution 4.0. This creative thinking ability is in accordance with the four competencies that students must have in the 2013 curriculum known as $4 \mathrm{C}$, namely critical, creativity, communication, and collaboratively. Arbia et al (2020) states that producing quality learning is necessary using a $4 \mathrm{C}$ strategy in learning but emphasizes the creative component more. Therefore, Biology as a lesson that prioritizes the development of thinking skills in analyzing, creating and applying concepts to everyday life situations can be used to train students' creative thinking collaboratively that can help students generate novelty problem-solving ideas.

The collaborative learning strategy known today is the lesson study for learning community pattern, because collaboration in learning is very important to support the learning process, both in collaboration between teachers, between teachers with students, and students with students. Lesson study for Learning community is a model of fostering the profession of educators through collaborative and sustainable learning studies based on the principles of collegiality and mutual learning to build a learning community (Lewis et.al., 2006). Lesson study for learning community is one way that can create an atmosphere of impassive learning, and interaction with each other in the learning process. Related to these descriptions, the research question that can be asked is whether students are able to learn in producing creative ideas on biological materials with lesson study for learning community patterns? Because according to Bermejo et.al (2016) that people can be very creative in certain domains such as literature, and music.

\section{Method}

This study used descriptive statistics that described objects studied through sample or population data as they were, without conducting analysis and making conclusions that applied to the public (Sugiyono, 2019). The results were a percentage of the gain presented in the form of a graph. The research sample was a Grade X IPA student at SMA Negeri 1 Masbagik consisted of 33 students. Data collection used a description test dealing with biodiversity, student test results were analyzed using Scale Range Formula (Umar, 2011), formula 1:

$$
\text { Mean }(R S)=\frac{n(m-1)}{m}
$$

Note :

$\mathrm{n}$ : Sample

$\mathrm{m}$ : The Alternative Answer

The description test refers to indicators of creative thinking ability, namely fluency, flexibility, and originality and each answer written by the student is given a score, the score is presented in table 1.

Table 1. Creative Thinking Indicators review score

\begin{tabular}{|c|c|c|c|}
\hline No & Indicator & Answer Criteria & Score \\
\hline \multirow[t]{3}{*}{1} & Fluency & $\begin{array}{l}\text { - Many more than } 2 \\
\text { and correct answer } \\
\text { ideas. }\end{array}$ & 3 \\
\hline & & $\begin{array}{l}\text { - Lots of } 2 \text { and } \\
\text { correct answer } \\
\text { ideas }\end{array}$ & 2 \\
\hline & & $\begin{array}{l}\text { - Many ideas answer } \\
2 \text {, one of which is } \\
\text { true }\end{array}$ & 1 \\
\hline
\end{tabular}




\begin{tabular}{|c|c|c|c|}
\hline No & Indicator & Answer Criteria & Score \\
\hline 2 & Flexibility & $\begin{array}{l}\text { - Answer ideas vary, } \\
\text { ideas are more than } \\
\text { 2, and correct Idea } \\
\text { - Varied answers, } 2 \\
\text { ideas and correct } \\
\text { Idea } \\
\text { - Varied answers, } \\
\text { ideas } 2 \text { and one of } \\
\text { them is true }\end{array}$ & 2 \\
\hline 3 & Originality & $\begin{array}{l}\text { - Answers that bring } \\
\text { up new and correct } \\
\text { ideas } \\
\text { - Answers that come } \\
\text { up with general } \\
\text { and correct ideas } \\
\text { - Unorthodox and } \\
\text { incorrect answers }\end{array}$ & 2 \\
\hline
\end{tabular}

Fatmawati (2014)

After obtaining the results from the calculation of the Scale Range formula, the results were categorized into three categories namely high, medium and low, the interval of values was presented in table 2 .

Table 2. Categories of students' creative thinking

\begin{tabular}{lll}
\hline No & Interval & Category \\
\hline 1 & $33-55$ & Low \\
2 & $56-77$ & Average \\
3 & $78-99$ & High \\
\hline
\end{tabular}

\section{Result and Discussion}

Designing the learning process that was implemented based on what students did in the classroom. Because students became the source of assessment, and input for the improvement of the next learning. Among teachers, applying new methods in the learning process was not easy, from teacher centered learning to student centered learning so that the learning environment became passive, the lack of high-level thinking skills of students, less creativity, less collaborative, and can also be less courageous to express opinions. Johnson (2002) revealed that if students are given the opportunity to use high levels of thinking skills in each grade level, they will be accustomed to sorting through information with logical arguments according to facts.

According to Smyrnaiou et.al (2020) argumentbased learning activities are an effective learning environment in learning that can give birth to students' creativity. Therefore, lesson study for learning community is one of the alternatives to familiarize the courage of learners in practicing their thinking, arguing, and arguing in discussion. Adams (2013) states that study lessons can help improve students' creative thinking. For creative thinking to occur in the classroom, educators need a clear understanding of concepts and the ability to translate them into practice (Gomes \&McCauley, 2021). To foster students' scientific creativity, teachers are proactive in taking initiative and always willing to learn to improve professionalism in teaching (Sidek et.al 2020).

Creative thinking is synonymous with the thought process that includes fluency (flexibility, and originality. Therefore, used a description test that is given a score on each indicator of creative thinking (results are presented on chart 1). A form of description tests to measure creative thinking skills is also used by (Listiana \&Bahri, 2019) which integrates with cognitive learning outcomes. Suparji et, al (2018) also uses three indicators of creative thinking, namely fluency, flexibility, and originality in his research.

Fluency is a smooth thinking, meaning the ability of a person in creating a lot number of ideas produced, flexibility is creating kinds of ideas means asking different types of ideas based on other points of view, and originality is creating other types of ideas than others, meaning ideas made unprecedented and logical. Evans (1991) defines the three indicators of creative thinking as follows fluency is the ability to bring up as many correct ideas or ideas as possible clearly. Flexibility is the ability to bring out a wide variety of ideas and ideas that are not monotonous by looking from various angles. Originality is the ability to generate unique or unusual ideas or ideas.

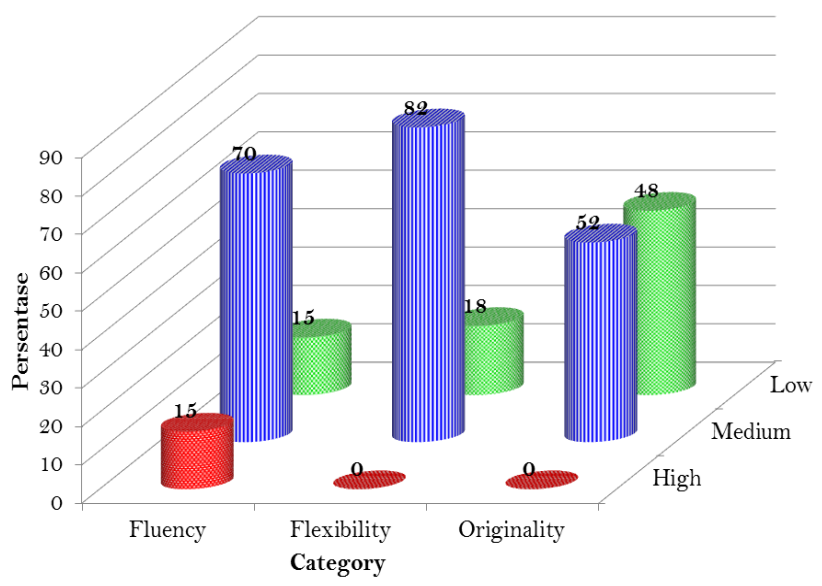

Figure 1. Percentage of students' creative thinking skills in biodiversity material with lesson study for learning community pattern

On the chart, shows that students' creative thinking skills were in the moderate (dominant) category with a percentage gain on the fluency 
indicator $(70 \%)$, flexibility (82\%) and originality (52\%). Low catechism acquired fluency (15\%), flexibility (18\%) and originality (48\%). Category was high only on fluency with a percentage of $15 \%$, while flexibility and originality obtained $0 \%$. The results of research from Wijayati et.al (2019) that the observation of students' creative thinking ability at the time of learning, only the fluency aspect stands out compared to flexibility, originality and elaboration.

Viewed from these results, it showed that students had not been able to create different types of ideas (flexibility) and created something new (originality). This possibility was due to the form of the description test question only measuring the cognitive levels of level 1 (C1) and level 2 (C2). The questions given by teachers sometimes rarely measured the high level of ability of students and in their learning.

Therefore, in teaching biological materials needed to be used to be implemented to the students dealing with the ability to think creatively on suitable materials. Guptaand \&Sharma (2019) states in science it takes a lot of imagination, and creative insights for new breakthroughs, major discoveries, and other scientific discoveries. In addition, Ritter et.al (2020) also suggested that with creativity training in learning can improve students' ideas skills and cognitive flexibility.

Creative thinking did not occur spontaneously to generate new ideas, it took process, and continuous practice in learning and daily life. Johnsosn (2002) revealed that if students are given the opportunity to use higher-order thinking skills at each grade level, they will eventually get used to sorting out information with logical arguments according to facts. High-level thinking, especially critical thinking, can be taught in contextual material, so that students can solve problems faced in everyday life.

If students need to be given essay questions and or assignments that lead to creative thinking, Risnanosanti et.al (2019) suggests that by giving assignments that are open questions allow students to find their own concepts/discoveries. Garcês (2018) also highlights creativity doesn't happen instantly, there are a series of underlying and interconnected stages in the creative process. Lince (2016) thought process as well as some of the intelligence that students have, modalities and learning style, wherever possible managed in order to be an effective learning strategy.

Furthermore, to creative thinking skills, several other indicators of success that can be observed in the learning process with lesson study patterns for learning community was the ability to communicate, argue, actualize themselves, respect each other, and explore themselves in learning. This was in accordance with the three philosophical lesson study for learning community namely openness (fairness), mutual respect (democracy), and everyone can be the best (Excellency). As stated by Conradty \& Bogner (2011) that with the atmosphere of the learning environment that follows the theory of constructivism, allows learners to follow individual conceptions and can be used as a guideline to integrate creativity. To apply this study lesson, of course, it needs to be adapted according to the characteristics of students, as done by Skott \& Møller (2020) concluding that to adapt study lessons, it is necessary to know the cultural characteristics of students. González \&Jason (2019) in his research mentioned that research on lesson study provides examples of the use of creativity frameworks to make Lesson Study can be carried out in other contexts. This also happens during the learning, students begin to get used to speaking to express their opinions in discussions but not all students, at least with the implementation of this LSLC students will get used to exploring themselves during the learning. Another finding from Kanauan and Inprasitha (2014) is that the implementation of this lesson study creates an atmosphere of collaborative collaboration between teachers and other observers to gain new experiences and knowledge. Other than, the implementation of this lesson study, according to Inprasitha \& Changsri (2014) it has can give impact to teachers on their perceptions with new teaching patterns. The same thing was stated by Wolthuis et.al (2020) that teachers tend to continue to do lesson study in their learning and consider it a useful teaching practice. Ngang \& Sam (2015) suggested that to implement this lesson study, support from the principal is needed because in the collaborative process the teachers jointly plan, deliver, observe and discuss lessons that have a specific pedagogical focus.

\section{Conclusion}

Creativity was important for students to learn in biology, such as in formulating new ideas to help students to solve their own problems. Based on the results of this study, it showed that with the learning pattern lesson study for learning community students can produce creative ideas with a moderate category that was above $50 \%$ on all indicators of creative thinking, namely fluency, flexibility, and originality. As for the low and high categories, the gain was below $50 \%$. To get used to getting students used to creative thinking, it took exercises in the creative thinking process such as giving tasks that leaded to creative thinking such as by applying constructive learning models. By applying the learning pattern lesson study for learning community, familiarize students to express themselves such as how to communicate, argue, and 
respect each other, so that a learning community was formed

\section{Acknowledgements}

Thank you to the principal of SMAN 1 Masbagik who have assisted in data collection, to the biology teacher of class $\mathrm{X}$ and students of class X IPA.

\section{References}

Adams, J. W. (2013). A case study: Using lesson study to understand factors that affect teaching creative and critical thinking in the elementary classroom. Drexel University.

Aguilar, D., \& Pifarre, T.M. (2019). Promoting social creativity in science education with digital technology to overcome inequalities: a scoping review. Frontiers Psychology, 10 (1474), 1-16. doi: 10.3389/fpsyg.2019.0147.

Arbia, S.M.,Maasawet, E.T., \& Masruhim, M.A. (2020). The development of learning tools oriented industrial revolution 4.0 to improve students' creative thinking skills. International Journal of Sciences: Basic and Applied Research (IJSBAR), 51 (2), 117-131.

Chan, S., \& Yuen, M. (2014). Creativity beliefs, creative personality and creativity-fostering practices of gifted education teachers and regular class teachers in Hongkong. Thinking Skills and Create, 14, 109-118. doi. https://doi.org/10.1016/j.tsc.2014.10.003.

Conradty, C., \& Bogner, F. (2011). Computer-aided learning: unguided versus guided instruction. Journal of Computational And Theoretical Nanoscience, 4(11), 3310-3316. doi. 10.1166/asl.2011.2040.

Conradty, C., Sotiriou, S.A, \& Bogner, F.X. (2020). How creativity in STEAM modules intervenes with self-efficacy and motivation. Education Science,10 (70), 1-15. doi:10.3390/educsci1.

Daud, A. M., Omar, J., Turiman, P., \& Osman, K.. (2012). Creativity in science education. Procedia - Social and Behavioral Sciences, 59, 467-474.

Diki. (2013). Creativity for learning biology in higher education. LUX: A Journal of Transdisciplinary Writing and Research from Claremont Graduate University, 3 (1), 1-13.

Evans, J.R. (1991). Creative thinking in the decision and management sceinces, $1^{\text {st }} \mathrm{ed}$. Ohio: South-Western Publishing Co.

Fatmawati, B. (2014). Identifikasi berpikir kreatif mahasiswa melalui metode mind mapping. Bioedukasi.7 (2), 35-41.
Garcês, S. (2018). Creativity in science domains: a reflection. Atenea 517. I Sem. 2018 I Sem, 201, 241-253.

Guptaand, P., \& Sharma, Y. (2019). Nurturing scientific creativity in science classroom. Resonance, 561574. doi: https://doi.org/10.1007/s12045-0190810-8.

Husna, I. A. \& Kurniasih, A. W. (2019). Student's creative thinking ability in problem-posing activities viewed from self-efficacy. Unnes Journal of Mathematics Education, 8(3), 202-208. doi: 10.15294/ ujme. v8i3.36593.

Inprasitha, M., \& Changsri, N. (2014). Teachers' beliefs about teaching practices in the context of lesson study and open approach. Procedia - Social and Behavioral Sciences, 116, 4637 - 4642. doi: 10.1016/j.sbspro.2014.01.999.

Kanauan, W., \& Inprasitha, N. (2014). Collaboration between Inservice teachers and student intern in thai lesson study. Procedia - Social and Behavioral Sciences, 116, 28 - 32 . doi: 10.1016/j.sbspro.2014.01.163

Lince, R. (2016). Creative thinking ability to increase student mathematical of Junior high school by applying models numbered heads together. Journal of Education and Practice, 7(6), 206 - 212.

Ngang, T.K., \& Sam, L.C. (2015). Principal Support in Lesson Study. Procedia - Social and Behavioral Sciences, 205, 134 - 139 . doi: 10.1016/j.sbspro.2015.09.040.

Risnanosanti, Susyla. D, \& Syofiana. M. (2019). Developing students critical thinking ability through lesson study. IOP Conf. Series: Journal of Physics: Conf. Series 1320 (2019) 012005 IOP Publishing. doi:10.1088/17426596/1320/1/01200, 1-8.

Ritter SM, Gu X., Crijns M., \& Biekens, P. (2020) Fostering students' creative thinking skills by means of a one-year creativity training program. PLoS ONE, 15(3), 1-18. doi:https://doi.org/10.1371/journal.pone.0229 $\underline{773}$.

Sandika, B., \& Fitrihidajati, H. (2018). Improving creative thinking skills and scientific attitude through inquiry-based learning in basic biology lecture toward students of biology education. Jurnal Pendidikan Biologi Indonesia, 4(1), 23-28. doi:https://doi.org/10.22219/jpbi.v4i1.5326.

Saptenno, A.E., Tuaputty, H., Rumahlatu, D., \& Papilaya, P.M. (2019). The improvement of learning motivation and creative thinking skills of senior high school students through modified problem based learning model. Journal for the Education of Gifted Young Scientists, 7(4), 1175-1194. 
scientific process skills. SHS Web of Conferences 48,
01060
(2018).
ERPA,
1-8.

doi:https://doi.org/10.1051/shsconf/20184801

060.

Sekar, D.K.S. (2017). The analysis of creative thingking ability in science subject matter of the fourth grade students in SD No. 2 Pemaron Buleleng Sub-Distric. Journal of Psychology and Instruction, 1(1), 19-27.

Skot, C.K., \& Møller, H. (2020). Adaptation of lesson study in a Danish context: Displacements of teachers' work and power relations. Teaching and Teacher Education, 87, 102945, 1-10. doi. https://doi.org/10.1016/j.tate.2019.102945.

Smyrnaiou, Z., Georgakopoulou, E., \& Sotiriou, S. (2020). Promoting a mixed-design model of scientific creativity through digital storytelling-the CCQ model for creativity. International Journal of STEM Education, 7 (25), 122. https://doi.org/10.1186/s40594-020-00223$\underline{6}$.

Sugiyono. (2019). Metode peneitian pendidikan. Bandung: Alfabeta.

Suparji, Nurlaela, L., \& Putra, B.A.W. (2018). Strategy to develop the ability of creative thinking using problem-based learning model in light vehicle engineering competences of vocational. Education. Advances in Social Science, Education and Humanities Research (ASSEHR), 201, 83-86.

Wadah, N., Rosyidah, A., Makmur, W., Susilo, H., \& Indriwati, S. (2018). Empowering biology students creative thinking skills in biology learning of $21^{\text {st }}$ century: guided inquiry-based lesson study. In Proceedings of the 2nd International Conference on Learning Innovation (ICLI), 153-158. doi: 10.5220/0008409201530158.

Wijayati, N., Sumarni, W., \& Supanti, S. (2019). Improving student creative thinking skills through project based learning. UNNES International Conference on Research Innovation and Commercialization 2018, KnE Social Sciences, 408-421. doi 10.18502/kss.v3i18.4732.

Wolthuis, F., Veen, K., Vries, S., \& Hubers, M.D. (2020). Between lethal and local adaptation: Lesson study as an organizational routine. International Journal of Educational Research, 100, 101534, 1-12. doi. https://doi.org/10.1016/j.ijer.2020.101534 